\title{
A Modified Shannon Trap for Use in Forensic Entomology
}

\author{
Maria Luiza Cavallari1,2*, Fabio Navarro Baltazar1,2, Erika Cristina de Carvalho1, \\ Daniel Romero Muñoz ${ }^{2}$, José Eduardo Tolezano ${ }^{1}$ \\ ${ }^{1}$ Centro de Parasitologia e Micologia, Instituto Adolfo Lutz, São Paulo, Brasil \\ ${ }^{2}$ Laboratório de Zoologia Médico-Legal, Departamento de Medicina Legal, Ética Médica, Medicina Social e do \\ Trabalho da Faculdade de Medicina da Universidade de São Paulo, São Paulo, Brasil \\ Email: *malu bio@hotmail.com
}

Received 7 January 2014; revised 18 February 2014; accepted 5 March 2014

Copyright (C) 2014 by authors and Scientific Research Publishing Inc.

This work is licensed under the Creative Commons Attribution International License (CC BY).

http://creativecommons.org/licenses/by/4.0/

c) (i) Open Access

\begin{abstract}
The objective of this study was to determine the efficacy of a modified Shannon trap to capture adult insects that are involved in cadaveric decomposition processes. The Shannon trap proposed here is composed of a thin fabric tent with a top formed by a transparent bottle containing a compartment filled with alcohol gel on which the captured insects are affixed. The trap was effective both for weather resistance and the quantity, quality and diversity of insects caught.
\end{abstract}

\section{Keywords}

Forensic Science, Flight Interception Trap, Diptera, Cadaveric Decomposition

\section{Introduction}

Forensic entomology is characterized by the use of insects, mites and other arthropods in legal procedures. Entomologic information allows the post morten interval (PMI) estimates to be obtained with reasonable accuracy, even after months of death. The study of cadaveric succession includes corpse necrophagous fauna analysis, which is based on the levels of decomposition. The fauna may vary because each period offers ideal conditions for the development of certain species. The development of the eggs and larvae is extremely predictable, and detailed observations of the biological stages of several insect species as well as their succession in the decaying corpse may reveal important information regarding the place and time of death [1].

Several traps can be used in forensic entomology to analyze the cadaveric entomofauna and to determine the relationship of the entomological succession with the phases of decomposition [2]-[5]. These traps are primarily "Corresponding author.

How to cite this paper: Cavallari, M.L., Baltazar, F.N., de Carvalho, E.C., Muñoz, D.R. and Tolezano, J.E. (2014) A Modified Shannon Trap for Use in Forensic Entomology. Advances in Entomology, 2, 69-75. 
characterized by the assembly of a rectangular iron framework that is usually clothed laterally by organza with an opening at the bottom to enable insects to enter the trap. Insect collection is generally performed manually using an entomological net wrapped over the top of the trap. However, some experiments do not use traps, and the insects are collected at the cadaver using insect hand nets [6]-[10]. For both methods, the researcher can collect the insects under the organza in addition to collecting the flying adults at the carcass. This practice may be harmful to the researcher, because these insects are known to be pathogen vectors [11] [12].

A similar trap was described by Shannon (1939) [13], and it was used primarily for the capture of day-flying sylvan mosquitoes and insects attracted by any type of bait. This trap consists of a rectangular compartment that is covered by muslin and four sides composed of mosquito netting. The trap is approximately $65 \mathrm{~cm}$ above ground with a large space below for the insects. The mosquitoes are caught with a suction tube inserted into a small opening in the side of the trap.

These traps remain assembled for undetermined lengths of time, thus allowing the collection of insects to visit the cadaver (or bait) throughout the day. However, without a bottle collector, the number of captured insects is low because many insects eventually die and fall to the ground and the nocturnal insects are not captured. In many experiments, oil is used as a fixative substance, which may alter the colors and structures of the insects that are prepared for identification.

In this study, we describe and test a modified Shannon trap for forensic entomology experiments. This trap has the following improvements: 1) collects the visiting insects during the entire decomposition process without prejudice based on the quantity and quality of the collected specimens, 2) prevents direct contact with the collected insects and 3) optimizes the time because of easy implantation that enables collection within a short period.

\section{Materials and Methods}

\section{Trap Description}

The trap proposed in this study consists of a voile textile tent fastened to the nozzle of a flask and fixed to the ground by four stakes, forming a pyramid with sides 10 to $30 \mathrm{~cm}$ from the ground to enable insect entry. The flask is fastened to two fixed points by its upper part, and there is an opening in the middle to which a collecting vial containing $70 \%$ gel alcohol is tied. Therefore, the collection is performed externally to the trap, and the insects are found adhered to the alcohol. The instructions for assembly are shown in Figure 1.

The trap was tested in experiments conducted in two distinct regions in Brazil between January and August, during the summer and winter seasons, respectively. The experiments were performed in the cities of São Paulo (at the campus of the Faculty of Medicine at the University of São Paulo, location $23^{\circ} 33^{\prime} \mathrm{S}$ and $46^{\circ} 40^{\prime} \mathrm{W}$ ) and Peruíbe (in the EEJI—Estação Ecológica Juréia-Itatins, location $24^{\circ} 22^{\prime} \mathrm{S}$ and $47^{\circ} 01^{\prime} \mathrm{W}$ ).

Four experiments were conducted, two during each season. The duration of each experiment was standardized to 20 days despite the variations in the decomposition periods of the carcasses at the two locations.

Swine carcasses weighing approximately $12 \mathrm{~kg}$ were placed directly on the ground inside $70 \times 50 \times 50 \mathrm{~cm}$ cages in shallow pits approximately $10 \mathrm{~cm}$ deep. This procedure was performed to protect the carcasses from vertebrate predators and to allow for adequate colonization. The cages were closed and strung in the surrounding vegetation to avoid predation as previously discussed. The trap was assembled above the cage to verify its efficacy and applicability for both experimental and forensics use. The collections were performed on alternating days at both locations.

After collection, the samples were transported to the laboratory and later grouped according to the decomposition phase. With the objective of evaluating the practical applicability of the trap in routine forensics, two collections with a one-hour interval were performed (the first collection at noon and the second collection at 1 p.m.). After this procedure, the collection vial was repositioned in the trap for additional collections.

\section{Results and Discussion}

A total of 10,833 arthropods that belonged to 53 families of insects were collected. The majority of the insects were from the order Diptera (96.9\%), but specimens from the orders Coleoptera (2.12\%), Hymenoptera (0.71\%), Lepidoptera (0.14\%), Hemiptera $(0.10 \%)$ and Orthoptera $(0.03 \%)$ were also observed. Table 1 shows the number of insects collected at each decomposition stage, and a quantitative analysis of the collected insects accord- 
ing to their taxonomic level of family is presented in Table 2.

The modified trap (Figure 2) retained the insects, and it was resistant to inclement weather. All of the collections were successful.

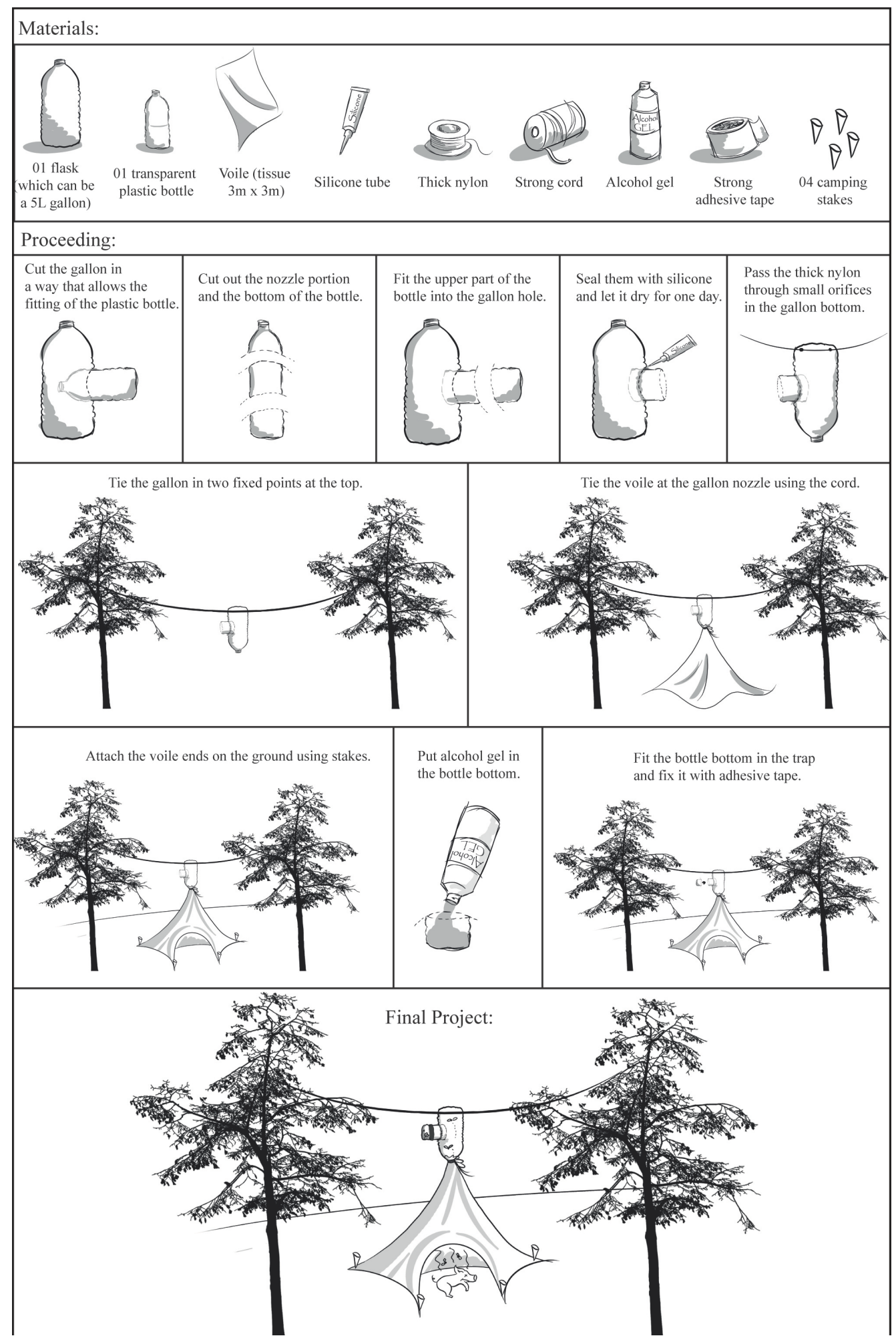

Figure 1. Step-by-step: assembly instructions trap. 
To test the functionality of the trap for experimental studies, the trap was maintained above the carcass during all phases of cadaveric decomposition. The collected insects were directly related to the phase during which they were found, thereby allowing analysis of the pattern of entomological succession. In addition, quantification of the collected insects made it possible to identify the abundance of the orders and families.

An evaluation of the efficacy of the number of specimens captured was performed by comparison with results from other studies that used similar traps or insect hand nets as shown in Table 3 [2]-[10]. Based on this analysis, our trap was more efficacious because of the increased number of insects captured during the process of decomposition and the variety of species captured.

To test the applicability of this trap for use in forensics, the quickness of assembly and the potential to collect insects in a short period were assessed. The results of both evaluations were positive because the implantation of the trap was simple and an estimated 30 to 80 insects were collected per hour.

Table 1. Number of insects collected by decomposition stage.

\begin{tabular}{ccccc}
\hline \multirow{2}{*}{ Stage of decomposition } & \multicolumn{3}{c}{ Number of specimens collected } \\
\cline { 2 - 5 } & EEJI-S $^{*}$ & SP-S $^{*}$ & EEJI-W $^{*}$ & SP-W $^{*}$ \\
\hline Fresh & 327 & 38 & 282 & 173 \\
Bloat & & 273 & 480 & 97 \\
Marbling & 746 & 378 & 1295 & 427 \\
Active decay & 1589 & 701 & 1428 & 558 \\
Skeletonization & 691 & 323 & 654 & 373 \\
Total & 3353 & 1713 & 4139 & 1628 \\
\hline
\end{tabular}

*EEJI-S-Peruíbe experiment during the summer. SP-S—São Paulo experiment during the summer. EEJI-WPeruíbe experiment during the winter. SP-W-São Paulo experiment during the winter.

Table 2. Total insects collected.

\begin{tabular}{|c|c|c|c|c|c|}
\hline \multirow{2}{*}{\multicolumn{2}{|c|}{ Order/Family }} & \multicolumn{4}{|c|}{ Abundance } \\
\hline & & \multirow{2}{*}{$\begin{array}{c}\text { EEJI-S }^{*} \\
-\end{array}$} & \multirow{2}{*}{$\begin{array}{c}\text { SP-S } \\
-\end{array}$} & \multirow{2}{*}{$\begin{array}{c}\text { EEJI-W* } \\
-\end{array}$} & \multirow{2}{*}{$\begin{array}{c}\text { SP-W* } \\
16\end{array}$} \\
\hline Coleoptera & Cleridae & & & & \\
\hline & Coccinellidae & - & - & 1 & 2 \\
\hline & Lathridiidae & 1 & - & - & - \\
\hline & Leiodidae & 2 & - & - & - \\
\hline & Staphylinidae & 192 & - & 15 & 1 \\
\hline \multirow[t]{17}{*}{ Diptera } & Anisopodidae & - & - & 1 & - \\
\hline & Anthomyiidae & 1 & - & - & 6 \\
\hline & Apioceridae & - & - & 1 & - \\
\hline & Calliphoridae & 286 & 93 & 757 & 806 \\
\hline & Ceratopogonidae & - & - & 1 & - \\
\hline & Chloropidae & - & - & 71 & 17 \\
\hline & Chyromyidae & - & - & 1 & - \\
\hline & Clusiide & - & - & 1 & - \\
\hline & Conopidae & - & - & 1 & - \\
\hline & Culicidae & - & - & 1 & - \\
\hline & Dolichopodidae & 14 & - & 29 & - \\
\hline & Drosophilidae & 13 & - & 91 & 79 \\
\hline & Empididae & - & - & 5 & - \\
\hline & Fannidae & 1401 & 348 & 1007 & 196 \\
\hline & Heleomyzidae & - & - & - & 1 \\
\hline & Lauxaniidae & - & - & 6 & - \\
\hline & Lonchaeidae & 1 & - & 28 & - \\
\hline
\end{tabular}




\section{Continued}

\begin{tabular}{ccccc}
\hline Micropezidae & 12 & 2 & 114 & - \\
Milichiidae & 90 & - & 81 & 6 \\
Muscidae & 268 & 91 & 445 & 203 \\
Mycetophilidae & - & - & 7 & 1 \\
Neriidae & - & - & 2 & 1 \\
Otitidae & 355 & 5 & 128 & 23 \\
Phoridae & 221 & 23 & 653 & 83 \\
Piophilidae & 28 & 16 & 49 & 15 \\
Pompilidae & - & - & 1 & - \\
Pteromalidae & - & - & 2 & - \\
Psillidae & - & - & - & 6 \\
Richardiidae & - & - & 2 & - \\
Ropalomeridae & - & - & 2 & - \\
Sarcophagidae & 118 & 92 & 165 & 94 \\
Sciaridae & - & - & 8 & 1 \\
Sepsidae & 270 & 1031 & 364 & 29 \\
Sphaeroceridae & - & - & 14 & 4 \\
Stratiomyidae & 37 & - & 3 & - \\
Strongylophtalmyiidae & - & - & 1 & - \\
Syrphidae & 8 & 3 & 20 & 1 \\
Tephritidae & - & 1 & - & - \\
Tethinidae & - & - & 26 & - \\
Tipulidae & - & - & 9 & - \\
Psyllidae & - & - & - & - \\
\hline
\end{tabular}

*EEJI-S—Peruíbe experiment during the summer. SP-S—São Paulo experiment during the summer. EEJI-WPeruíbe experiment during the winter. SP-W—São Paulo experiment during the winter.

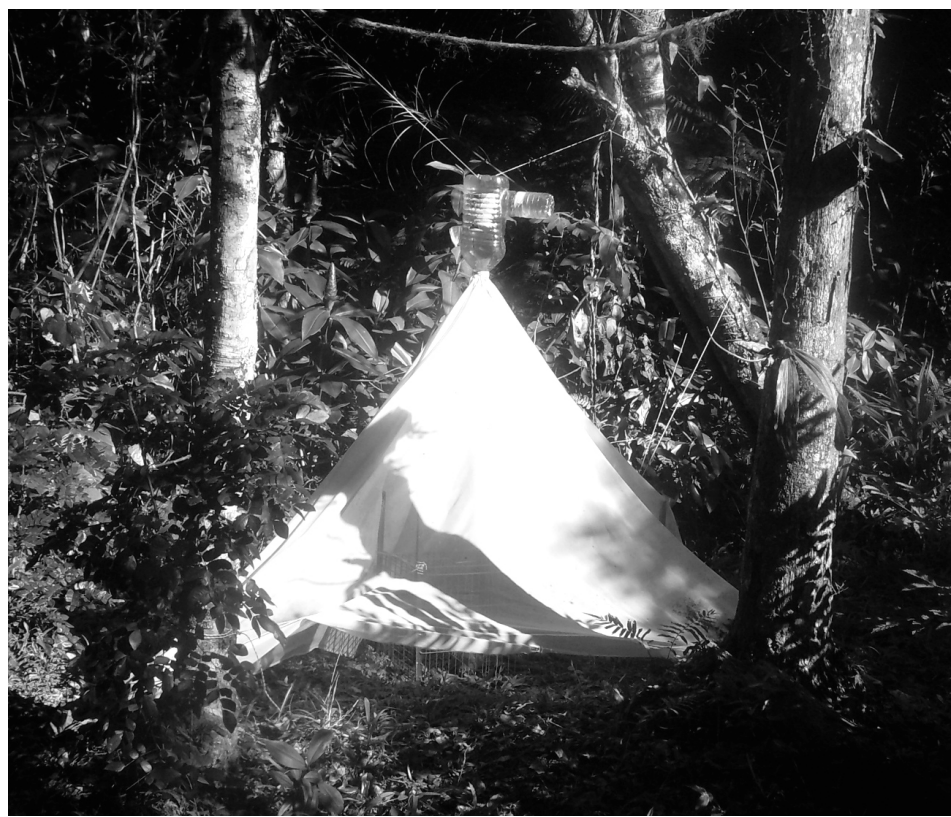

Figure 2. Demonstrative image trap. 
Table 3. Comparision with results from other studies.

\begin{tabular}{|c|c|c|c|c|c|}
\hline Reference & Local & $\begin{array}{l}\text { Type of } \\
\text { collection }\end{array}$ & $\begin{array}{l}\text { Time/number of } \\
\text { experiments }\end{array}$ & $\begin{array}{l}\text { Number of collected } \\
\text { specimens }\end{array}$ & $\begin{array}{c}\text { Number of } \\
\text { identified families }\end{array}$ \\
\hline $\operatorname{Ref}[2]$ & Mountainous Area & Trap with squid bait & $\begin{array}{l}-90 \text { consecutive days } \\
-9 \text { traps } \\
\text { - } 54 \text { collections }\end{array}$ & $\begin{array}{l}\text { Total: 19,676 Calliphoridae } \\
\text { samples, averaging } 364 \\
\text { copies per bait }\end{array}$ & $\begin{array}{l}11 \text { species of } \\
\text { Calliphoridae }\end{array}$ \\
\hline \multirow{3}{*}{$\operatorname{Ref}[3]$} & $\begin{array}{c}\text { Forest Area } \\
\text { (650 m altitude) }\end{array}$ & $\begin{array}{l}\text { Trap with a } 5.5 \times 7 \mathrm{~cm} \\
\text { container for bait }\end{array}$ & $\begin{array}{l}\text { - } 12 \text { months } \\
\text { - } 12 \text { experiments }\end{array}$ & $\begin{array}{l}\text { Total: 25,995 dipteran, } \\
\text { averaging } 2166 \text { samples per } \\
\text { experiment }\end{array}$ & \multirow{3}{*}{$\begin{array}{l}13 \text { families of } \\
\text { Diptera }\end{array}$} \\
\hline & $\begin{array}{c}\text { Forest Area } \\
\text { (1120 m altitude) }\end{array}$ & $\begin{array}{l}\text { Trap with a } 5.5 \times 7 \mathrm{~cm} \\
\quad \text { container for bait }\end{array}$ & $\begin{array}{l}\text { - } 12 \text { months } \\
\text { - } 12 \text { experiments }\end{array}$ & $\begin{array}{l}\text { Total: } 14,185 \text { dipteran, } \\
\text { averaging } 1182 \text { samples per } \\
\text { experiment }\end{array}$ & \\
\hline & $\begin{array}{c}\text { Forest Area } \\
\text { (1550 m altitude) }\end{array}$ & $\begin{array}{l}\text { Trap with a } 5.5 \times 7 \mathrm{~cm} \\
\quad \text { container for bait }\end{array}$ & $\begin{array}{l}-6 \text { months } \\
-6 \text { experiments }\end{array}$ & $\begin{array}{l}\text { Total: } 2475 \text { dipteran, } \\
\text { averaging } 412 \text { specimens } \\
\text { per experiment }\end{array}$ & \\
\hline $\operatorname{Ref}[4]$ & Cerrado Area & $\begin{array}{l}\text { Air pet bottle trap with } \\
\text { ground beef bait }\end{array}$ & $\begin{array}{l}\text { - } 60 \text { days } \\
-3 \text { traps } \\
\text { (simultaneously) }\end{array}$ & $\begin{array}{l}\text { Total: } 5976 \text { dipteran, } \\
\text { averaging } 1992 \text { samples per } \\
\text { experiment (each } 60 \text { days) }\end{array}$ & 4 families of Diptera \\
\hline $\operatorname{Ref}[5]$ & Urban Area & $\begin{array}{c}\text { Tissue trap and } \\
\text { collection with insect } \\
\text { net }\end{array}$ & $\begin{array}{l}\text { - } 1 \text { year } \\
-12 \text { experiments } \\
\text { (approx. } 26 \text { days each) }\end{array}$ & $\begin{array}{l}\text { Total: } 258 \text { Calliphoridae } \\
\text { specimens, averaging } 64 \\
\text { per experiment }\end{array}$ & $\begin{array}{l}4 \text { species of } \\
\text { Calliphoridae }\end{array}$ \\
\hline $\operatorname{Ref}[6]$ & Semi-Rural Area & $\begin{array}{l}\text { Insect net over bait } \\
\text { (pig carcass) }\end{array}$ & $\begin{array}{l}\text { - } 97 \text { days } \\
\text { - about } 40 \text { collections }\end{array}$ & $\begin{array}{l}\text { Total: } 3382 \text { insects } \\
\text { (Diptera and Coleoptera) }\end{array}$ & $\begin{array}{l}10 \text { families of } \\
\text { Diptera }\end{array}$ \\
\hline $\operatorname{Ref}[7]$ & Forest Area & $\begin{array}{l}\text { Insect net over bait } \\
\text { (pig carcass) }\end{array}$ & $\begin{array}{l}-1 \text { year } \\
-12 \text { experiments } \\
\text { (trials } 3 \times \text { daily) }\end{array}$ & $\begin{array}{l}\text { The number of specimens is } \\
\text { not available }\end{array}$ & $\begin{array}{l}4 \text { species of } \\
\text { Calliphoridae }\end{array}$ \\
\hline $\operatorname{Ref}[8]$ & Urban Area & $\begin{array}{l}\text { Insect net over bait } \\
\text { (pig carcass) }\end{array}$ & - 42 days & $\begin{array}{l}\text { The number of specimens is not } \\
\text { available }\end{array}$ & $\begin{array}{l}2 \text { families of } \\
\text { Diptera }\end{array}$ \\
\hline $\operatorname{Ref}[9]$ & Forest Area & $\begin{array}{l}\text { Insect net over bait } \\
\text { (rodent carcass) }\end{array}$ & $\begin{array}{l}\text { - } 1 \text { year } \\
\text { - } 32 \text { experiments } \\
\text { (daily collections) }\end{array}$ & $\begin{array}{l}\text { Total: } 820 \text { samples } \\
\text { ( } 4 \text { orders), average of } 25 \text { per } \\
\text { carcass }\end{array}$ & $\begin{array}{l}13 \text { families of } \\
\text { Diptera }\end{array}$ \\
\hline Ref [10] & Forest Area & $\begin{array}{l}\text { Insect net over bait } \\
\text { (pig carcass) }\end{array}$ & $\begin{array}{l}\text { - } 1 \text { year } \\
\text { - } 4 \text { experiments ( } 40 \\
\text { days; daily collections) }\end{array}$ & $\begin{array}{l}\text { Total: 11,996 Diptera' } \\
\text { samples, averaging } 2999 \\
\text { per experiment }\end{array}$ & $\begin{array}{l}24 \text { families of } \\
\text { Diptera }\end{array}$ \\
\hline \multirow{2}{*}{$\begin{array}{l}\text { Present } \\
\text { experiment }\end{array}$} & Forest Area & $\begin{array}{l}\text { Present trap, with pig } \\
\text { carcasses as bait }\end{array}$ & $\begin{array}{l}\text { - } 2 \text { experiments } \\
\text { - } 30 \text { days each }\end{array}$ & $\begin{array}{l}\text { Total: } 7942 \text { insects samples } \\
\text { ( } 5 \text { orders), averaging } 3746 \text { per } \\
\text { experiment }\end{array}$ & $\begin{array}{l}39 \text { families of } \\
\text { Diptera }\end{array}$ \\
\hline & Urban Area & $\begin{array}{l}\text { Present trap, with pig } \\
\text { carcasses as bait }\end{array}$ & $\begin{array}{l}\text { - } 2 \text { experiments } \\
\text { - } 30 \text { days each }\end{array}$ & $\begin{array}{l}\text { Total: } 3341 \text { insects samples } \\
\text { ( } 4 \text { orders), averaging } 1670 \text { per } \\
\text { experiment }\end{array}$ & $\begin{array}{l}21 \text { families of } \\
\text { Diptera }\end{array}$ \\
\hline
\end{tabular}

\section{Conclusion}

We conclude that the trap showed favorable results. Its low cost, ease of manufacturing and efficient collection and preservation of the specimens captured facilitates further identification and characterization of necrophagous fauna. Furthermore, this study demonstrated that the trap met the expectations of feasibility related to the duration of the experiments, the number and quality of the specimens captured and the richness of the species collected. Therefore, this trap can serve as a complementary resource for forensics practice and experimentation.

\section{Acknowledgements}

We thank Prof. Dr. Silvio Nihei for help reviewing the text, and Julia Albuquerque and Igor Caricaturas for help with the language and figures.

\section{References}

[1] Oliveira-Costa, J. (2008) Entomologia forense: Quando os insetos são vestígios. 2nd Edition, Millennium Editora, 
Campinas.

[2] Baz, A., Cifrian, B., Díaz-Aranda, L.M. and Martín-Veja, D. (2007) The Distribution of the Adult Blowflies (Diptera: Calliphoridae) along an Altitudinal Gradient in Central Spain. Annales de la Société Entomologique de France, 43, 289-296. http://dx.doi.org/10.1080/00379271.2007.10697524

[3] Morón, M.A. and Terrón, R.A. (1984) Distribuición altitudinal y estacional de los insectos necrófilos em La sierra Norte de Hidalgo México. Acta Zoologica Mexicana, 3, 1-47.

[4] Castro, R.C.S., Dias, D.X., Sujii, E.R. and Queiroz, P.R. (2010) Levantamento de dípteros de interesse forense em uma área de cerrado em Brasília. Universitas: Ciências da Saúde, Brasília, 8, 1-16.

[5] Beuter, L., Fernandes, P.A., Barros, P.B., Souza, C.R., Jacomini, L.B. and Mendes, J. (2008) Diversidade e sazonalidade de califorídeos de potencial importância forense na área urbana de Uberlândia. Anais do XII Seminário de Iniciação Científica da Universidade Federal de Uberlândia, Uberlândia, UFU.

[6] Segura, N.A., Bonilla, M.A., Usaquén, W. and Bello, F. (2011) Entomofauna Resource Distribution Associated with Pig Cadavers in Bogotá DC. Medical and Veterinary Entomology, 25, 46-52. http://dx.doi.org/10.1111/j.1365-2915.2010.00933.x

[7] Sabanoglu, B. and Sert, O. (2010) Determination of Calliphoridae (Diptera) Fauna and Seasonal Distribution on Carrion in Ankara Province. Journal of Forensic Sciences, 55, 1003-1007. http://dx.doi.org/10.1111/j.1556-4029.2010.01366.x

[8] Anderson, G.S. (2011) Comparison of Decomposition Rates and Faunal Colonization of Carrion in Indoor and Outdoor Environments. Journal of Forensic Sciences, 56, 136-142. http://dx.doi.org/10.1111/j.1556-4029.2010.01539.x

[9] Moretti, T., Ribeiro, O.B., Thyssen, P.J. and Solis, D.R. (2008) Insects on Decomposing Carcasses of Small Rodents in a Secondary Forest in Southeastern Brazil. European Journal of Entomology, 105, 691-696. http://dx.doi.org/10.14411/eje.2008.094

[10] Carvalho, L.M.L. and Linhares, A.X. (2001) Seasonality of Insect Succession and Pig Carcass Decomposition in a Natural Forest Area in Southeastern Brazil. Journal of Forensic Sciences, 46, 604-608.

[11] Greenberg, B. (1971) Flies and Disease, Ecology, Classification and Biotic Association. Annals of the Entomological Society of America, 83, 1210-1214.

[12] Thyssen, P.J., Moretti, T.C., Ueta, M.T. and Ribeiro, O.B. (2004) O papel de insetos (Blattodea, Diptera e Hymenoptera) como possíveis vetores mecânicos de helmintos em ambiente domiciliar e peri-domiciliar. Cadernos de Saúde Pública, 20, 1096-1102. http://dx.doi.org/10.1590/S0102-311X2004000400025

[13] Shannon, R.C. (1939) Methods for Collecting and Feeding Mosquitoes in Jungle Yellow Fever Studies. American Journal of Tropical Medicine and Hygiene, 19, 131-140. 